\title{
Long-term survival with Gemcitabine alone chemotherapy for non-metastatic advanced pancreatic cancer ; One case
}

\author{
비전이성 진행 췌장암에서 Gemcitabine 단독 항암 화학요법을 통한 장기 생존 1예
}

Department of Surgery, Kangbuk Samsung Hospital, Sungkyunkwan University School of Medicine, Seoul, Korea

Hyung Ook Kim, M.D. · Hungdai Kim, M.D., Ph.D. · Jun Ho Shin, M.D., Ph.D.

성균관대학교 의과대학 강북삼성병원 외과학교실 김 형 욱, 김 흥 대, 신 준 호

\section{초 록}

복부 전산화 단층 촬영 및 조직병리 검사상 비전이성 진행 췌장 암 진단 하에 개복술을 통한 고식적 총담관공장문합술을 시행 받 고, 수술 후 gemcitabine 단독 항암 화학요법으로 종양의 진행 이나 수술 및 항암 화학요법에 따른 특별한 합병증 없이 30 개월 이상 장기 생존하고 있는 69 세 남자 환자를 문헌 고찰과 함께 보 고한다.

중심 단어 : 췌장암, 폐쇄성 황달, 고식적 치료

\section{서 론}

국내 중앙암등록본부 및 통계청 자료에 따르면 2003 2005년 췌장암은 전체 암 발생의 $2.6 \%$ 를 차지하며, 2006 년 암으로 인한 사망의 $5.3 \%$ 를 차지한다. 췌장암은 다른 암에 비하여 발생 빈도 는 낮으나 조기 진단이 어렵고 주변 장기로의 전이가 많아 진단 당시 약 $40 \sim 50 \%$ 에서 원격전이가 발견된다. ${ }^{1,2)}$ 또한 원격전이가 없더라도 주요 혈관의 침윤이나 수술 범위를 벗어난 림프절로의 전이 등으로, 진단 당시 절제가 가능한 경우는 전체 췌장암의 약 $10 \sim 20 \%$ 만을 차지한다. ${ }^{2,3)}$ 따라서 원격전이는 없으나 절제가 불 가능한 약 30 40\%의 비전이성 진행 췌장암에 대하여 항암 화학 요법, 방사선치료, 또는 이들의 병합요법 등에 대한 여러 연구들 이 진행되고 있다. ${ }^{4,5)}$

외과적인 절제가 불가능한 대부분의 췌장암 환자에게서 치료의 주된 목적은 황달, 위장관 폐색 및 통증의 경감이다. 저자들은 완 치를 기대할 수 있는 유일한 방법으로, 대부분의 진행 췌장암 환

책임저자 : 신준호

$110-746$ 서울시 종로구 평동 108 강북삼성병원 외과

Tel : 02-2001-2138, Fax: 02-2001-2131, E-mail : junho0521.shin@samsung.com

접수일 : 2009년 4월 10일 ; 게재승인일 : 2009년 5월 7일
자들에게 개복술을 권하고 있으며, 개복 당시 근치적 절제가 불가 능 할 경우 황달, 위장관 폐색 및 통증의 치료를 위하여 고식적 수 술을 시행하고 있다.

본 증례의 환자는 개복술을 통한 고식적 총담관공장문합술 (Roux-en-Y choledochojejunostomy)과 gemcitabine 단독 항암 화학요법을 통하여 30개월 이상의 장기 생존을 보이기 에 문헌 고찰과 함께 이를 보고하는 바이다.

\section{증 례}

69 세의 남자 환자로 약 2 개월 전부터 발생된 복부 불편감과 약 1 주일 전부터 발생된 황달을 주소로 내원하였다. 내원 당시 혈액 검사상 백혈구 $3,820 / \mathrm{mm}^{3}$, 헤모글로빈 $14.3 \mathrm{~g} / \mathrm{dL}$, 혈소판 $231,000 / \mathrm{mm}^{3}$ 이었으며, 총빌리루빈 $14.0 \mathrm{~g} / \mathrm{dL}, \mathrm{GOT} / \mathrm{GPT}$ $157 / 261 \mathrm{IU} / \mathrm{L}, \mathrm{CA} 19-915.37 \mathrm{U} / \mathrm{mL}$ 이었다. 내시경적 역행성 췌담도조영술상 근위부 총담관 및 간내 담관의 확장과 원위부 총 담관의 협착을 관찰할 수 있었으며, 췌두부 췌관의 협착과 췌장 체부 및 미부 췌관의 불규칙한 확장이 관찰되어 췌두부암을 의심 할 수 있었다. 복부 전산화 단층 촬영상 췌두부의 주췌관에 약 $1.0 \mathrm{~cm}$ 크기의 조영 증강을 보이는 경계가 분명한 종괴와 상장간 막동맥을 감싸고 있는 약 $2.0 \mathrm{~cm}$ 크기의 연부조직 음영을 보이는 종괴가 관찰되었으며 이 종괴는 상장간막동맥의 근위부까지 확대 되어 있었고, 또한 간문(portahepatis) 주위에 여러 크기의 $1 \mathrm{~cm}$ 미만의 림프절들이 관찰되었다(Fig. 1).

진행 췌두부암의 추정 진단 하에 개복술을 시행하였으며, 수술 중 간문 주위의 림프절과 상장간막동맥을 감싸고 있는 종괴의 동 결절편조직검사(frozen biopsy)상 고분화도의 전이성 선암종 (metastatic adenocarcinoma, well-defferentiated)이 진단되었다. 근치적 절제가 불가능할 것으로 사료되어 고식적 총 담관공장문합술을 시행하였다. 
환자는 수술 21 일 후에 특별한 합병증 없이 퇴원하였으며, 수술 후 27일부터 gemcitabine 단독 항암 화학요법을 시행하였다. 투여 방법은 처음 7주간 일주일에 한번씩 gemcitabine $1000 \mathrm{mg} / \mathrm{m}^{2}$ 을 1 시간 동안 지속 투여하고, 일주일 쉰 뒤 이후부 터는 같은 용량을 3 주 투여 후 1주 쉬는 일정으로 지속 투여하였 다. 매 3 개월 간격으로 복부 전산화 단층 촬영을 시행하여 항암 화학요법에 따른 반응에 대하여 RECIST(response evaluation criteria in solid tumors)를 기준으로 평가하였다.

항암 화학요법 3 개월 후 시행한 복부 전산화 단층 촬영상 종양 의 크기는 약 $30 \%$ 감소하여 부분 관해(partial response, PR) 를 보였으며(Fig. 2), 약 30개월 이상 지난 현재까지 복부 전산화 단층 촬영상 종양의 크기 증가 없이 생존하고 있다(Fig. 3).

항암 화학요법 시행 중 $1 \sim 3$ 도의 호중구감소증과 1 도의 혈소판 감소증이 관찰되었으나 그에 따른 증상은 발생되지 않았으며, recombinant human GM-CSF 등의 투여 또는 추적 관찰만으 로 호전되어 항암 화학요법의 연기나 감량 등은 없었다.

\section{고 찰}

원격 전이가 없는 췌장암의 근치적 절제에 대한 적응증은 현재 까지도 여러 논쟁의 여지가 있으나, 일반적으로 종양이 상장간막 동맥이나 복강동맥(celiac trunk)을 감싸고 있거나 대동맥이나 하대정맥으로의 침윤, 상장간막정맥이나 문맥(portal vein)의 폐 색, 또는 절제 범위를 벗어난 부위로의 림프절 전이가 있는 경우 에는 근치적 절제가 불가능한 것으로 판단되고 있다. 이러한 비전 이성 진행 췌장암의 빈도는 전체 췌장암의 약 30 40\%를 차지하 고 있어 이에 대한 치료 방침을 정하는 것이 중요할 것으로 생각 된다. ${ }^{2}$

진행 췌장암에 대한 항암 화학요법에는 5-fluorouracil(5$\mathrm{FU})$, gemcitabine 단독요법 또는 병용요법, bevacizum$\mathrm{ab}$ (Avastin)이나 cetuximab(Erbitux)과 같은 표적 치료제 등 이 사용되고 있으며, ${ }^{4-7)}$ 현재까지는 NCCN(national comprehensive cancer network) guideline에서 gemcitabine 단독요법이 표준 치료(Category 1)로 확립되어 있다. 여러 연구 에서 비전이성 진행 췌장암에 대한 gemcitabine 단독요법 후 중 간 생존기간(median survival)은 5.6 11.7개월이었다. ${ }^{4}$ 일부 전향적 연구들에서 gemcitabine을 기본으로 하는 병용요법이나 화학방사선치료(chemoradiotherapy)를 통하여 생존기간을 늘일 수 있다는 보고가 있으나, 아직까지는 그 효과의 차이가 크 지 않은 것으로 판단된다. ${ }^{4,5}$

수술적 절제가 불가능한 췌장암 환자는 생존기간 동안 폐쇄성 황달, 위장관 폐쇄, 그리고 통증 등으로 고통 받게 된다. 최근까지 폐쇄성 황달에 대한 고식적 치료로 내시경적 또는 경피적 담도배
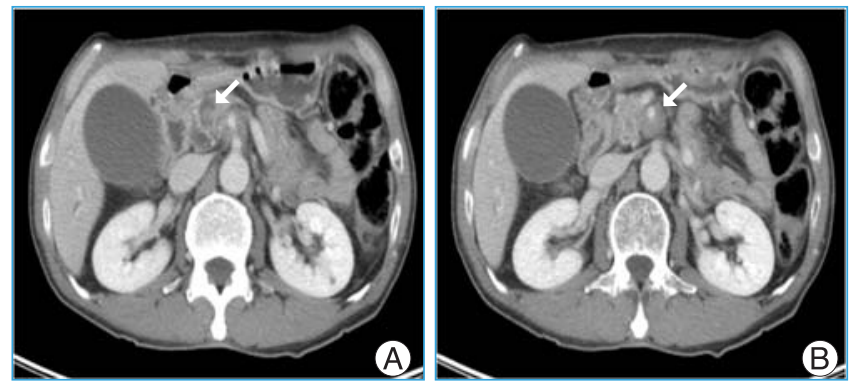

Fig. 1. Preoperative computed tomography scans. A) About $1 \mathrm{~cm}$ sized, well-defined enhancing nodular mass (arrow) in main pancreatic duct of pancreas head, B) About $2 \mathrm{~cm}$ sized, soft tissue density mass (arrow) encasing superior mesenteric artery, which extend to mesenteric root.
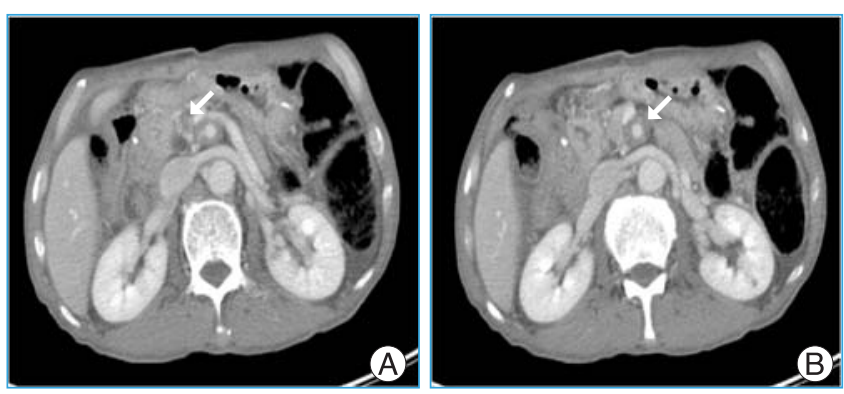

Fig. 2. Postoperative ( 3 months after gemcitabine alone chemothetapy) computed tomography scans. A) Mass (arrow) in main pancreatic duct of pancreas head decreased in size. B) Soft tissue density mass (arrow) encasing superior mesenteric artery decreased in size.
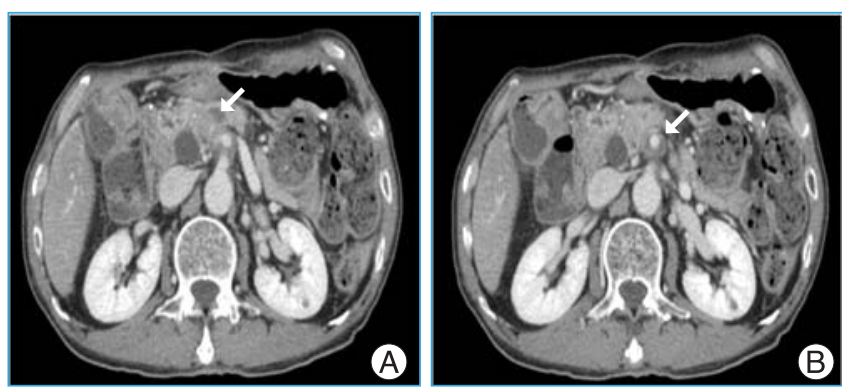

Fig. 3. Computed tomography scans at about 30 months after gemcitabine alone chemothetapy ( 30 cycles). A) No remarkable interval change in size of mass (arrow) in main pancreatic duct of pancreas head. B) No remarkable interval change in size of soft tissue density mass (arrow) encasing superior mesenteric artery.

액술에서 많은 발전이 있었다. 하지만, 이러한 비수술적 담도배액 술은 수술에 비해 술기에 따른 합병증을 감소시킬 수는 있으나 수 술적 담도배액술에 비하여 폐쇄성 황달의 재발이 흔하다. ${ }^{8,9}$ 본 저 자의 이전 연구에서 수술적 담도배액술은 환자의 총 생존기간을 연장시키고, 생존기간 동안 폐쇄성 황달이나 담도염의 재발을 감 소시켜 생존의 질을 향상시키는 것으로 평가되었다. ${ }^{10)}$ 이 환자에 서도 수술적 담도배액술을 시행하였으며, 수술 후 고식적 항암 화 
학요법 동안 황달의 재발이나 담도염의 발생은 없었다. 항암 화학 요법 동안 이러한 국소 합병증이 발생된다면 항암 치료를 연기 또 는 중단할 수밖에 없으며, 이 기간 동안 종양의 진행을 억제하지 못했을 것이다. 하지만 고식적 항암 화학요법 전 폐쇄성 황달 등 에 대한 치료방법에 대하여는 향후 전향적 비교연구가 필요할 것 으로 생각된다.

본 저자들은 비전이성 진행 췌장암 환자에서 고식적 수술을 통 한 폐쇄성 황달 등의 국소 증상의 해소와 수술 후 gemcitabine 단독 항암 화학요법을 통하여 종양의 부분 관해와 30 개월 이상의 장기 생존을 경험하였기에 문헌 고찰과 함께 보고하는 바이다.

\section{REFERENCES}

1. Jemal A, Siegel R, Ward E, Hao Y, Xu J, Murray T, et al. Cancer statistics, 2008. CA Cancer J Clin 2008;58:71-96.

2. Reznek RH, Stephens DH. The staging of pancreatic adenocarcinoma. Clin Radiol 1993;47:373-381.

3. Pasquali C, Sperti C, Filipponi C, Pedrazzoli S. Epidemiology of pancreatic cancer in Northeastern Italy: incidence, resectability rate, hospital stay, costs and survival(1990-1992). Dig Liver Dis 2002;34:723-731.

4. Ben-Josef E, Lawrence TS. Chemoradiotherapy for unre- sectable pancreatic cancer. Int J Clin Oncol 2008;13:121-126.

5. Okusaka T, Ito Y, Furuse J, Yamada S, Ishii H, Shibuya K, et al. Current status of chemoradiotherapy for locally advanced pancreatic cancer in Japan. Int J Clin Oncol 2008;13:127-131.

6. Kindler HL, Friberg G, Singh DA, Locker G, Nattam S, Kozloff M, et al. Phase II trial of bevacizumab plus gemcitabine in patients with advanced pancreatic cancer. J Clin Oncol 2005;23:8033-8040.

7. Xiong $H Q$, Rosenberg A, LoBuglio A, Schmidt W, Wolff RA, Deutsch $J$, et al. Cetuximab, a monoclonal antibody targeting the epidermal growth factor receptor, in combination with gemcitabine for advanced pancreatic cancer:a multicenter phase II Trial. J Clin Oncol 2004;22:2610-2616.

8. van den Bosch RP, van der Schelling GP, Klinkenbijl JH, Mulder PG, van Blankenstein M, Jeekel J. Guidelines for the application of surgery and endoprostheses in the palliation of obstructive jaundice in advanced cancer of the pancreas. Ann Surg 1994;219:18-24. 9. Smith AC, Dowsett JF, Russell RC, Hatfield AR, Cotton PB. Randomised trial of endoscopic stenting versus surgical bypass in malignant low bileduct obstruction. Lancet 1994;344:1655-1660. 10. Kim HO, Hwang SI, Kim H, Shin JH. Quality of survival in patients treated for malignant biliary obstruction caused by unresectable pancreatic head cancer:surgical versus non-surgical palliation. Hepatobiliary Pancreat Dis Int 2008;7:643-648. 


\title{
Long-term survival with Gemcitabine alone chemotherapy for non-metastatic advanced pancreatic cancer; One case
}

\author{
Department of Surgery, Kangbuk Samsung Hospital, Sungkyunkwan University School of Medicine \\ Hyung Ook Kim, M.D. · Hungdai Kim, M.D., Ph.D, · Jun Ho Shin, M.D., Ph.D.
}

\begin{abstract}
We report a 69-year-old male patient with non-metastatic advanced pancreatic cancer confirmed by abdominal computed tomography and intraoperative biopsy. He presented with long-term survival more than 30 months without disease progression or complication following palliative surgery and chemotherapy, after palliative choledochojejunostomy and postoperative gemcitabine alone chemotherapy.
\end{abstract}

Key Words : Pancreatic cancer, Obstructive jaundice, Palliation

Correspondence : Jun Ho Shin, M.D.

Department of Surgery, Kangbuk Samsung Hospital, Sungkyunkwan University School of Medicine, 108 Pyung-Dong, Jongro-Ku, Seoul 110-746, South Korea.

TEL : 82-2-2001-2138, FAX : 82-2-2001-2131, E-Mail : junho0521.shin@samsung.com

Received : April 10, 2009; Accepted : May 7, 2009 